Doi: $10.4274 / \mathrm{Npa}$.Y5857

\title{
Poems Sendromu ve Multisentrik Castleman Hastalığında Ağrılı Polinöropati: Olgu Sunumu
}

\section{Painful Polyneuropathy in Poems Syndrome with Multicentric Castleman Disease: A Case Report}

\author{
Selen GÜR, Feza DEYMEER*, Piraye OFLAZER* ${ }^{*}$, Yeşim Gülşen PARMAN* \\ İstanbul Bilim Üniversitesi Tıp Fakültesi, Nöroloji Anabilim Dalı, Istanbul, Türkiye \\ *Istanbul Üniversitesi Istanbul Tıp Fakültesi, Nöroloji Anabilim Dalı, Istanbul, Türkiye
}

\section{ÖZET}

POEMS sendromu monoklonal plazma hücre diskrazisi ile ilişkili olan nadir bir multisistemik hastalıktır. Polinöropati hastalığın majör kritelerindendir, buna karşılık lenf nodlarının non-klonal bir hastalı̆ı olan Castleman hastalığı ise hastalığın minör kriterlerinden biridir. Bu olguda ön planda çok şiddetli ağrının eşlik ettiği sensori-motor tipte subakut polinöropati tablosu ile başlayan POEMS sendromu, multisentrik Castleman hastalığı ile ilişkilendirilmiştir. Ağrılı polinöropati tablosu ile ortaya çıkan ve monoklonal gammopati saptanan hastalarda POEMS sendromunun kriterlerinin sorgulanması ve ileri incelemelerle hastalığın tanısının kesinleştirilmesi, tedaviyle iyi prognoz ihtimali olan hastalarda morbiditeyi azaltarak sağ kalımın artmasını sağlayacak bir yaklaşım olabilir. (Nöropsikiyatri Arşivi 2011; 48: 211-4)

Anahtar Kelimeler: POEMS sendromu, ağrılı polinöropati, castleman hastalı̆̆ı, monoklonal gammopati

\begin{abstract}
POEMS is a rare syndrome which is associated with monoclonal plasma cell dyscrasia. Although polyneuropathy is one of the major criteria, Castleman disease is a minor criteria. Herein, we report a patient with a painful sensory-motor polyneuropathy, who is diagnosed with POEMS syndrome and also has multicentric Castleman disease. Monoclonal gammopathy presenting with painful polyneuropathy can be associated with POEMS syndrome. Keeping this association in mind would decrease morbidity in patients who probably have a good prognosis. (Archives of Neuropsychiatry 2011; 48: 211-4) Key words: POEMS syndrome, painful neuropath, Castleman disease, monoclonal gammopathy
\end{abstract}

\section{Giriş}

POEMS sendromu monoklonal plazma hücre diskrazisi ile ilişkili olan nadir bir multisistemik hastalıktır. Crow-Fukase sendromu ve Takatsuki sendromu olarak da adlandırılır (1-3).

POEMS akronimi 1980 yılında Bardwick ve arkadaşları tarafından hastalığın 5 karakteristik özelliği olan polinöropati, organomegali, endokrinopati, monoklonal gammopati ve deri bulguIarının baş harfleri kullanılarak oluşturulmuştur.

POEMS sendromunda Castleman hastalığının eşlik ettiği durumlarda çok nadiren ağrılı sensori-motor polinöropatinin klinik tabloya hakim olduğu birkaç olgu bildirilmiştir (4).

Bu bildiride, ön planda çok şiddetli ağrının olduğu sensorimotor tipte subakut polinöropati tablosu ile başlayan POEMS sendromu olgusu, Castleman hastalığı ile ilişkilendirilmiştir.

\section{Olgu Sunumu}

Kırk üç yaşında, özgeçmişinde bilinen bir hastalığı olmayan, ilaç kullanmayan, 20 yıldır günde bir küçük şişe rakı kullanımı ve 30 paket yıl sigara kullanımı olan hasta ayak parmaklarında yanma, kuvvetsizlik, her iki ayağının tamamında şiddetli ağrı ve ellerde uyuşukluk yakınmalarıyla başvurdu. Öyküsünde ayaklarındaki kuvvetsizlik, yanma ve ağrı yakınmalarının yaklaşık 1 sene önce başladığı ve son birkaç aydır ağrı ve yanmalarına yürüme zorluğunun eklendiği, ellerindeki uyuşmanın ise son birkaç aydır olduğu öğrenildi. Soygeçmişinde hipertansiyon, diabetes mellitus ve iskemik kalp hastalığı vardı.

Hasta zayıftı, yüzünde ve vücudunda yaygın hiperpigmentasyon olduğu izlenimi alınmakla birlikte hasta deri renginde değişiklik tanımlamıyordu. Nörolojik muayenesinde bilinci açıktı, ko- 
operasyonu ve oryantasyonu tamdı. Konuşması normaldi. Ense sertliği ve meningeal irritasyon bulguları yoktu. Kranyal alan muayenesi normaldi. Kas gücü el parmak fleksörleri ve interosseuslarda 4/5, iliopsoaslarda 4/5, tibialis anteriorlarda 3/5, gastrokinemiuslarda 4/5, ekstensör hallusis longuslarda 0/5, diğer kas gruplarında tamdı. Yüzeyel duyu muayenesinde üst ve alt ekstremite distallerinde hipoestezi vardı. Vibrasyon algısı iç maleollerde çok kısaydı. Pozisyon duyusu üstte normal, altta bozuktu. Derin tendon refleks muayenesinde üstte iki yanlı triseps, biseps ve brakiyoradyal refleksler hipoaktifti, altta patella ve Achilles refleksleri alınamadı. Taban deri refleksi iki yanlı cevapsızdı. Romberg pozitifti. Adım aralığı genişti. Sfinkter kusuru yoktu.

Hemogram incelemesinde WBC: $11530 \mathrm{~mm}^{3}$ (4000-11000), RBC: 5.43 milyon/mm3 (4.4-5.4 milyon), HGB:15,7 g/dl (12-18), HCT:48.27 \% (37-50), MCV:88.86fl (80-100), MCH:29.02 (27-31), PLT:438000/mm3 (150000-400000), CRP 24.81 Sedimentasyon 17 $\mathrm{mm} / \mathrm{saat}$ idi. Rutin biyokimyasında glukoz:80 mg/dl (70-100), BUN:5 mg/dl (8-22), Kreatinin:0,6 mg/dl (0.7-1.4), Na:140 mmol/L (135-146), K:4.5 mmol/L(3.5-5.1), Cl:104 mmol/L(95-107), AST:13 U/L (5-42) ALT:13 U/L (5-45) FT3:3.0 pmol/L (3.1-6.8), FT4:13.9 $\mathrm{pmol} / \mathrm{L}(12-22), \mathrm{TSH}: 3.49$ (0,27-4,2), B12 vitamini: $974.8 \mathrm{pg} / \mathrm{ml}($ 191-663), Pıhtılaşma zamanı:13.3 sn (10-15), PT:\% 75.4 (70-130), INR:1.17 (0.85-1.20), aPTT: 27.1 (19.5-29.1), troponin-T:<0.010 $\mathrm{ng} / \mathrm{ml}(<0.010)$ idi. EKG normal sinüs ritmindeydi.

Lomber ponksiyonda açılış basıncı normal, BOS berrak, renksizdi. BOS biyokimyasında glukoz: $74 \mathrm{mg} / \mathrm{dl}$, protein: $1063 \mathrm{mg} / \mathrm{L}$, direkt bakıda boyasız 172/mm³ hücre, lenfosit $4 / \mathrm{mm}^{3}$ $\mathrm{PML} 1 / \mathrm{mm}^{3}$ vardı.

EMG incelemesinde üst ekstremitelerde motor ileti hızlarının 35-38 m/sn aralığında myelin disfonksiyonuna işaret edecek değerler gösteriyordu. Alt ekstremitelerde ise simetrik akson kaybını gösteren bulgular vardı. Hastada üst ekstremitede hakim demiyelinizan, alt ekstremitede aksonal özellikteki EMG bulguları ağır demiyelinizasyona sekonder aksonal etkilenme olarak değerlendirildi. Sural sinir biyopsisinin progresyonu süren aksonal nöropatiyle uyumlu bulunmasının nedeninin de bu durum olabileceği düşünüldü. BOS protein yüksekliğiyle birlikte olan subakut seyirli polinöropatinin ayırıcı tanısında kronik inflamatuvar demiyelinizan polinöropati (KIDP) ile birlikte bu tabloya yol açabilecek gammopati gibi başka polinöropati nedenleri de düşünüldü. Kronik alkol kullanımı olan hastada alkole bağlı toksik polinöropati ayırıcı tanıda yer alsa da, beslenme yetersizliği ve karaciğer yetmezliği bulguları olmadığından bu tanıdan uzaklaşıldı.

Ayak tabanlarındaki yanma ve çok şiddetli ağrı yakınması için daha önce denenmiş olan gabapentin ve tramadol tedavilerinden fayda görmediği öğrenilen hastaya başlanan Pregabalin 2x300 mg dozuna kadar yükseltildi ayrıca amitriptilin 1x75 mg tedavisine eklendi. Bu tedaviler ile hastanın ağrı ve yanma yakınması hafifledi. Klinik ve patolojik progresyonu önlemek amacıyla hastaya prednizon (Deltacortril@) $60 \mathrm{mg} /$ gün başlandı.

Protein elektroforezinde M-spike (\%1.9) tespit edildi. İmmünfiksasyonda IgA lambda tipi monoklonal gammapati görüldü. İdrarda hafif zincir görülmedi. Gammopatinin sebebini araştırmaya yönelik yapılan periferik yayma normaldi. Toraks BT'de pretrakeal alanda büyüğü $11.5 \times 6 \mathrm{~mm}$ boyutlarında lenf nodları, infrakarinal düzeyde 11x8 mm, prevasküler alanda 7x4 mm, sağ hiler alanda $5 \times 4 \mathrm{~mm}$ boyutlarında lenf nodu saptandı. Batın BT'de dalak boyutu $16 \mathrm{~cm}$ olarak artmıştı, paraaorto-kaval alanda oldukça fazla sayıda en büyükleri sağ böbrek alt pol düzeyinde, sağ paraaortik 23×15 boyutlarında, iliak bifürkasyon düzeyinde sol paraaortik 19×15 mm boyutlarında her iki iliak zincirde oldukça fazla sayıda en büyüğü sağ eksternal iliak, internal iliak arter ayrımı düzeyinde lateral komşuluğunda 33x24 mm boyutlarında ve aynı düzeyde solda $28 \times 18$ boyutlarında patolojik görünümlü lenf nodları saptandı.

Hematoloji tarafından da değerlendirilen hastada var olan M-spike, lenfadenopatiler ve splenomegaliyle birlikte polinöropati tablosunun olması nedeniyle klinik tablonun POEMS sendromuyla uyumlu olduğu düşünüldü. Daha önce başka bir merkezde yapılmış olan inguinal lenf nodu biyopsisinin I.Ü Tıp Fakültesi Patoloji Bölümü tarafından tekrar değerlendirilmesi sağlandı. Morfolojik olarak yer yer hyaline vasküler tip Castleman hastalığını düşündüren sekonder lenfoid foliküller, interfolliküler alanlarda oldukça belirgin plazmositoz saptanarak, Castleman hastalığıyla uyumlu olarak bulundu.

Kemik iliği biyopsisinde hafif derecede hemosiderin artışı gösteren normosellüler kemik iliği saptandı. Hastanın tekrarlanan nörolojik muayenelerinde Prednizon 60 mg altındayken sağ el distalinde özellikle oppozisyon yapan kaslarda kuvvetsizliğin arttığı ve o elde derin duyunun bozulduğu bu nedenle hastanın sağ eliyle cep telefonunu kullanamayacak düzeye geldiği dikkati çekti.

İncelenen uzun kemik grafilerinde hastada litik veya sklerotik lezyon saptanmamakla birlikte PET-CT'te sol asetabulum inferiorunda sklerotik lezyon ve bu alanda hafif dereceli hipermetabolizma izlendi. Bu lezyonun myeloproliferatif bir hastalığın tutulumu ile ilişkili olabileceği gibi benign kemik patolojisi de düşünülebileceği rapor edildiğinden ayırıcı tanısı için MR ile korelasyonu önerildi. Kokso-femoral MR'da sol asetabulum posteriorunda $32 \times 15 \mathrm{~mm}$ boyutlarında periferik hafif halkasal kontrast tutulumu gösteren T1 hipointens, T2 heterojen hiperintens, kortekste destrüksiyon yapmayan, benign natürde non-spesifik kitle olarak tanımlandı. Ortopedi kliniği tarafından değerlendirilerek asetabuler kitlenin benign özellikte olma ihtimalinin yüksek olduğu düşünüldü fakat BT eşliğinde Tru-cut biyopsi yapılması önerildi. Radyolojiyle görüşüldü teknik nedenlerden ötürü bu tetkik ertelenmek zorunda kaldı.

Önceden kronik alkol kullanımı olduğu için hepatoloji tarafından olası karaciğer hasarı açısından değerlendirildi ve problem saptanmadı.

Hematoloji konseyine çıkarılan hastanın tedavisi deksametazon $40 \mathrm{mg} /$ gün oral (ayın 1-4, 9-12, 17-20. günlerinde almak üzere) olarak değiştirildi. En az üç kür sonrası batın BT ve asetabulum MR kontrol, polinöropati derecesinin değerlendirilmesi, M bandı, hafif zincir oranının kontrol edilmesi ve 3 ay sonra konseye tekrar çıkarılmasına karar verilerek taburcu edildi.

\section{Tartışma}

POEMS sendromuna plazma hücre hastalığının neden olduğu bilinmektedir fakat altta yatan hastalık mekanizması ve semptomların ortaya çıkışı arasındaki patofizyolojik bağlantı çok net anlaşılmamıştır. Bazı sitokinlerin ve bu hastalarda yük- 
sek oranda bulunan ve tedaviyle düzeyi düşen VEGF (büyüme faktörü)'deki değişikliklerin bu hastalığa yol açıyor olabileceği üzerinde durulmaktadır (5-7).

Tanı kriterleri 2003 yılında Dispenzieri ve arkadaşlarının 99 hastalık serisine dayanılarak oluşturulmuştur. POEMS sendromunda sitokin düzeylerindeki değişikliklerin hastalıkta rolü olabileceği hakkında yayınların artmasıyla Arimura ve arkadaşları yüksek VEGF düzeylerini tanı kriteri olarak önermiştir. Buna göre; 2 majör kriter ve 1 minör kriter tanı için yeterlidir. Minör kriterlerden osteosklerotik lezyon veya Castleman hastalığı nerdeyse her zaman vardır. Majör kriterler: Polinöropati, monoklonal plazma hücreli- proliferatif bozukluk. Minör kriterler: Sklerotik kemik lezyonları, Castleman hastalığı, organomegali (splenomegali, hepatomegali, lenfadenopati), ödem (ödem, plevral efüzyon, asit), endokrinopati (adrenal, tiroid, pitüiter, gonadal, paratiroid, pankreatik), deri değişiklikleri (hiperpigmentasyon, hipertrikoz, pletora, hemangiomata, beyaz tırnak), papilödem. Bilinen eşlik eden durumlar: Çomak parmak, kilo kaybı, trombositoz, polisitemi, hiperhidroz. Muhtemelen eşlik eden durumlar: Pulmoner hipertansiyon, restriktif akciğer hastalığı, trombotik diatez, artralji, kardiyomyopati, ateş, düşük B12 düzeyi, diyare.

Hastamızda majör kritelerin hepsi var iken, minör kriterlerden sklerotik kemik lezyonu, Castleman hastalığı, splenomegali, lenfadenopati, deri değişikliklerinden hiperpigmentasyon vardı. Bütün POEMS sendromlu hastalarda olan ve klinikte en ön planda olan periferik nöropati bizim olgumuzda da ön plandaydı (8).

Castleman hastalığı Dr.Benjamin Castleman tarafından 1956 yılında tanımlanmış aynı zamanda anjiofoliküler hiperplazi olarak da anılan, lenf nodlarının non-klonal bir hastalığıdır. İki histolojik tipi vardır. Bunlar hyaline-vasküler foliküller ve beraberinde interfoliküler kapiller proliferasyonun olduğu tip ve plazma hücreleriyle infiltre olmuş büyük foliküllerden oluşan plazma hücreli varyanttır (9). Lokalize ve multisentrik olarak iki farklı klinik prezantasyonu vardır. Unisentrik Castleman hastalığında mediastinum veya mezenterik bölgede yavaş büyüyen soliter tek bir lenf nodu ve bunun lokal etkisine bağlı olabilecek semptomlar vardır, çok nadiren sekonder patolojik klonal-sitogenetik bulgular eşlik eder. Cerrahi rezeksiyon ile \%90-95 kür sağlanır ve 5 yıllık sağ kalım \%100'dür. Multisentrik Castleman hastalığında ise yaygın lenfadenopati görülmekle birlikte, bazen hepatosplenomegali, bitkinlik, gece terlemesi, ateş, kilo kaybı, iştahsızık klinik tabloya eşlik eder. Hyaline vasküler Castleman hastalığı lokalize Castleman hastalığının \%90'ında bulunurken olguların sadece \%3-10'unda sistemik klinik özellikler eşlik eder. Öte yandan plazma hücreli varyantı lokalize Castleman hastalığının \%10'unda görülürken multisentrik Castleman hastalığının \%8090 'ında saptanır (10). Bizim olgumuzda yaygın lenfadenopati ve splenomegali olduğundan klinik tablo multisentrik Castleman hastalığı ile uyumludur. Ayrıca inguinal lenfadenopatiden alınan biyopsi örneğinin histopatolojik incelemesinin plazma hücreli varyantı göstermesi de bu durumu desteklemektedir.

POEMS sendromun majör klinik özelliği motor tutulumun ön planda olduğu kronik progresif sensorimotor polinöropatidir. Semptomlar ayaklarda üşüme, uyuşma, yanma gibi duyusal yakınmalarla başlar ve ardından motor yakınmalar klinik tabloya eklenir. Distal, simetrik, progresif olan semptom ve bulgular proksimale doğru yayılır. Hızlı progresyon da bazı olgularda görülebilir. Bazı hastalarda ağrı olabileceği biliniyor olsa da genel olarak ağrılı polinöropati tablolarında ayırıcı tanıda çoğunlukla vaskülitler, diyabetes mellitus, kriptojenik duyusal veya duyusal-motor polinöropati, amiloidoz, Guillain Barre sendromu, talyum veya arsenik gibi toksinlerin neden olduğu polinöropatiler, HIV ile ilişkili distal simetrik polinöropati, Fabry hastalığı (11) gibi başka hastalıklar ön planda akla gelmektedir. Ayrıca nöropatinin karakteristik özellikleri KIDP özelliklerine benzediği için de hastalara yanlış olarak KIDP veya önemi bilinmeyen monoklonal gammopati (MGUS)'ye bağlı periferik nöropati tanısı konabilmektedir (8). Hastamızda var olan polinöropati tablosunun önce alt ekstremite distalinde simetrik başlayıp subakut seyir gösteren motor ve duyusal polinöropati tablosu olması ve üst ekstermitede de yayılım göstermesi daha önceden POEMS sendromu ve Castleman hastalığıyla birlikte görülerek tanımlanmış polinöropati tabloları ile uyumluydu. Fakat polinöropati tablosunda ağrının ön planda olması daha önce bu tip olgularda çok nadir tanımlanmış ve üzerinde çok fazla durulmamış bir özellikti. Hastanın ön plandaki yakınmaları kuvvet kaybından çok ayak tabanlarında şiddetli yanma ve ayaklarının mengene ile sıkıştırılıyormuş gibi ağrımasıydı.

EMG incelemesinde üst ekstremitede demyelinizan, alt ekstremitede aksonal özellikteki EMG bulguları daha önce tanımlanmış polinöropatinin eşlik ettiği Castleman hastalığı olan birkaç olgunun incelemeleriyle uyumluydu (12).

Sural sinir biyopsisinin progresyonu süren aksonal nöropatiyle uyumlu bulunması ve primer demyelinizan özellikler göstermiyor olması EMG'nin alt ekstremite bulgularıyla uyumluydu.

Olgumuzda yapılan PET-CT incelemesinde saptanan sol asetabulum inferiorundaki sklerotik lezyonun kokso-femoral MR'da periferik hafif halkasal kontrast tutulumu gösteren T1 hipointens, T2 heterojen hiperintens, kortekste destrüksiyon yapmayan benign natürde non-spesifik kitle olması radyolojik özelliklerinin soliter kemik plazmasitomuyla uyumlu olabileceğini düşündürmektedir (13). Biyopsi yapılamadığı için bu tanı henüz konulamamıştır. POEMS sendromunda plazmasitom varlığında lokal radyoterapiden olguların faydalandığı ve hayatta kalımı arttırdığı bilinmektedir. Biyopsi bizim olgumuzda eksik kalmış ve tamamlanması gerekli olan bir incelemedir.

POEMS sendromunda ortalama yaşam bir dekattan fazladır (14). Efüzyon, ödem, asit gibi ekstrasellüler volüm artışına neden olan durumlar ve çomak parmak daha kısa sağkalım ile ilişkili iken Castleman hastalığı, serum ve idrar M proteini, trombositoz, papilödem, yaş, alkilleyici ilaç kullanımı, kemik lezyonlarının sayısı sağkalımda belirleyici bulunmamıştır $(15,16)$.

POEMS sendromunun standard bir tedavisi yoktur. Öncelikle destek tedavi, osteosklerotik kemik lezyonu olanlarda radyoterapi (15), yüksek doz kemoterapiyi izleyen otolog periferik kan kök hücre nakli (17-19), alkilleyici ajanlar (3,15,20), kortikosteroidler $(3,15)$ tedavide kullanılan yöntemlerdir.

Olgumuzun tedavisine hematoloji bölümüyle görüşülerek başlandı. Deksametazon 40 mg oral (ayın 1-4, 9-12, 17-20. günlerinde almak üzere) olarak değiştirildi. En az üç kür sonrası batın BT ve asetabulum MR kontrol, polinöropati derecesinin değerlendirilmesi, $\mathrm{M}$ bandı, hafif zincir oranının kontrol edilmesi ve 3 ay sonra tekrar değerlendirilerek otolog periferik kan kök hücre nakli açısından tartışılmasına karar verilerek taburcu edildi. 
Ağrilı polinöropati tablosu ile prezante ve monoklonal gammapati saptanan hastalarda POEMS sendromunun kriterlerinin sorgulanması ve ileri incelemelerle hastalığın tanısının kesinleştirilmesi, tedaviyle iyi prognoz intimali olan hastalarda morbiditeyi azaltarak sağ kalımın artmasını sağlayacak bir yaklaşım olabilir. Olgumuz bu nedenle sunulmaya değer bulunmuştur.

\section{Kaynaklar}

1. Crow RS. Peripheral neuritis in myelomatosis. Br Med J 1956; 2:802-4.

2. Bardwick PA, Zvaifler NJ, Gill GN ve ark. Plasma cell dyscrasia with polyneuropathy, organomegaly, endocrinopathy, $\mathrm{M}$ protein and skin changes: the POEMS syndrome: report on two cases and a review of the literature. Medicine (Baltimore) 1980; 59:311-22.

3. Nakanishi T, Sobue I, Toyokura Y et al. The Crow-Fukase syndrome: a study of 102 cases in Japan. Neurology 1984; 34:712-20.

4. Ku A, Lachmann E, Tunkel R et al. Severe polyneuropathy: initial manifestation of Castleman's disease associated with POEMS syndrome. Arch Phys Med Rehabil 1995; 76:692-4.

5. Watanabe 0, Maruyama I, Arimura K et al. Overproduction of vascular endothelial growth factor/vascular permeability factor is causative in Crow-Fukase (POEMS) syndrome. Muscle Nerve 1998; 21:1390-7.

6. Arimura K. Increased vascular endothelial growth factor (VEGF) is causative in Crow-Fukase syndrome. Rinsho Shinkeigaku 1999; 39:84-5.

7. Scarlato $M$, Previtali S C, Carpo $M$ et al. Polyneuropathy in POEMS syndrome: role of angiogenic factors in the pathogenesis. Brain 2005 128:1911-20.

8. Dispenzieri A. Hematology Am Soc Hematol Educ Program. 2005; 360-7.
9. Keller AR, Hochholzer L, Castleman B. Hyaline-vascular and plasmacell types of giant node hyperplasia ofthe mediastinium and other locations. Cancer 1972: 29:670-83.

10. Waterston A, Bower M. Fifty years of multicentric Castleman's disease. Acta Oncol 2004; 43:698-704.

11. Wolfe GI, Barohn RJ. Painful Peripheral Neuropathy. Curr Treatm Options in Neurology 2002; 4:177-88.

12. Donaghy $\mathrm{M}$, Hall $\mathrm{P}$, Gawler $\mathrm{J}$ et al. Peripheral neuropathy associated with Castleman's disase. Jorn of Neuro Scien 1989; 89:253-67.

13. Dimopoulos M, Moulopoulos L, Maniatis A et al. Solitary plasmacytoma of bone and asymptomatic multiple myeloma. Blood 2000; 96:2037-44.

14. Dispenzieri A. POEMS syndrome. Blood Rev 2007; 21:285-99.

15. Dispenzieri A, Kyle RA, Lacy MO et al. POEMS syndrome: definitions and long-term outcome. Blood 2003; 101:2496-506.

16. Allam JS, Kennedy CC, Aksamit TR et al. Pulmonary manifestations are common and associated with shortened survival in POEMS syndrome:A retrospective review of 137 patients. Chest 2008; 133:969-74.

17. Imai N, Taguchi J, Yagi N et al. Relapse of polyneuropathy, organomegaly, endocrinopathy, M-protein and skin changes (POEMS) syndrome without increased level of vascular endothelial growth factor following successful autologous peripheral bloodstem cell transplantation. Neuromuscul Disord 2009; 19:363-5.

18. Sonada S, Ookawara S, Karube $\mathrm{H}$ et al. Marked recovery of severe renal lesions inPOEMS syndrome with high dose melphalan therapy supported by autologous blood stem cell transplantation. Am J Kidney Dis 2006; 47:672-9.

19. Rovira M, Carreras E, Blade J et al. Dramatic improvement of POEMS syndrome following autologues haematopoietic cell transplantation. Br J Haematol 2001; 115:373-5.

20. Kuwabara S, Hattori T, Shimoe Y et al. Long-term melphalan-prednisolone chemotherapy for POEMS syndrome. J Neurol Neurosurg Psychiatry 1997; 63:385-7. 